\title{
PEMAHAMAN TENTANG REMAJA DAN PERMASALAHANNYA
}

\author{
Suharni \\ Program Studi Bimbingan dan Konseling \\ Fakultas Keguruan dan Ilmu Pendidikan \\ Universitas PGRI Yogyakarta \\ E-mail: suharni911@gmail.com
}

\begin{abstract}
Abstrak
Kedudukan dan fungsi suatu keluarga dalam kehidupan manusia bersifat primer dan fundamental. Keluarga merupakan kesatuan yang terkecil di dalam masyarakat tetapi menepati kedudukan yang primer dan fundamental, oleh sebab itu keluarga mempunyai peranan yang besar dan vital dalam mempengaruhi kehidupan seorang anak. Demikian pula jika keluarga tidak dapat menciptakan suasana pendidikan, maka hal ini akan menyebabkan anak-anak terperosok atau tersesat jalannya. Keluarga mempunyai peranan dalam proses sosialisasi anak adalah sebagai berikut, 1) keluarga merupakan kelompok terkecil yang anggotanya berinteraksi to face secara tetap, 2) orang tua mempunyai motivasi yang kuat untuk mendidik anak karena anak merupakan cinta kasih hubungan suami istri, 3) karena hubungan sosial dalam keluarga itu bersifat relatif tetap maka orangtua memainkan peranan sangat penting terhadap proses sosialisasi anak. Lingkungan yang kurang kondusif dan sifat keperibadian yang kurang baik akan menjadi pemicu timbulnya berbagai penyimpangan perilaku dan perbuatan-perbuatan negatif yang melanggar aturan dan norma yang ada.
\end{abstract}

Kata kunci: bimbingan dan konseling, kesulitan belajar, sekolah menengah umum

\begin{abstract}
The position and function of a family in human life is primary and fundamental. The family is the smallest unity in society but fulfills the primary and fundamental position, therefore the family has a big and vital role in influencing a child's life. Similarly, if the family can not create an atmosphere of education, then this will cause children to get mired or lost their way. The family has a role in the process of socialization of children is as follows, 1) the family is the smallest group whose members interact to face permanently, 2) parents have a strong motivation to educate children because the child is a love relationship husband and wife, 3) because of social relations In the family is relatively fixed then the parents play a very important role to the process of socialization of children. A less conducive environment and poor personality traits will trigger the emergence of various deviations of behavior and negative actions that violate existing rules and norms.
\end{abstract}

Keywords: guidance and counseling, learning difficulties, general high school

\section{Info Artikel}

Diterima Maret 2017, disetujui April 2017, diterbitkan Juni 2017 


\section{PENDAHULUAN}

Keluarga adalah lingkungan pertama dan utama dalam melaksanakan proses sosialisasi pribadi seorang anak. Di tengah keluarga anak berusaha mengenal berbagai macam nilai dan norma yang ada di lingkungannya. Keluarga memberikan pengaruh sekaligus membentuk watak dan kepribadiaan anak, sehingga keluarga dikatakan sebagai unit sosial terkecil yang memberikan dasar bagi perkembangan anak (Soekanto, 2012). Globalisasi memberikan dampak yang luar biasa dalam berbagai sendi kehidupan ibuibu dasawisma, tidak terkecuali dalam kehidupan berkeluarga.

Pengaruh globalisasi dalam kehidupan berkeluarga terlihat pada pergeseran nilai dan norma dalam keluarga, seperti bergesernya nilai keharmonisan keluarga, nilai orang tua, nilai anak dan lain sebagainya. Contohnya, orang tua zaman sekarang sibuk dengan pekerjaan masingmasing sehingga banyak tugas dan peran di keluarga menjadi dikesampingkan. Orang tua berpendapat bahwa ketika mencari uang dan dapat digunakan untuk memenuhi kebutuhan anak itu sudah lebih dari cukup, padahal yang dibutuhkan anak bukan hanya pemenuhan kebutuhan fisik, tetapi justru lebih kepada pemberian kasih sayang melalui pendampingan secara psikologis (Ritzer, 2004). Kondisi seperti ini akan sangat terlihat pada keluarga di perkotaan, di mana pola kehidupan ibuibu dasawismanya yang cenderung gesselschaft (patembayan), ditandai dengan memudarnya nilainilai kekeluargaan dan kebersamaan.

Seperti halnya yang terjadi pada sebagian besar keluarga yang bertempat tinggal di dusun yang padat penduduknya dengan populasi anak dan remaja sangat besar. Populasi yang sangat besar tersebut berpotensi menciptakan berbagai permasalahan remaja, dari kenakalan remaja yang bersifat ringan sampai berat. Apabila peran keluarga tidak bisa maksimal maka permasalahan tersebut akan menjadi permasalahan sosial yang dapat mengganggu kehidupan beribuibu dasawisma. Selain itu letaknya yang strategis di daerah perkotaan membuat ibu-ibu dasawismanya dapat dengan mudah mengakses berbagai informasi dan alat pemuas kebutuhan hidup yang lain. Kemudahankemudahan tersebut apabila tidak diiringi dengan filter keluarga dan kesiapan mental setiap individu dalam ibu-ibu dasawisma, maka akan menimbulkan culture lag (ketimpangan budaya) dan culture shock (goncangan budaya) yang dapat berakibat negatif pada pembentukan kepribadian anak.

Dari analisis situasi yang telah dipaparkan di atas, maka dapat diidentifikasi permasalahan mitra, yaitu: adanya tuntutan pekerjaan dan tuntutan hidup terkadang memaksa orang tua untuk mengesampingkan tugas dan kewajibannya, sehingga tanpa disadari menimbulkan efek 
negatif bagi anak, contohnya karena anak kurang kasih sayang dan perhatian orang tua maka anak tumbuh menjadi pribadi yang nakal, suka berbohong, suka berkelahi, suka berbuat onar dll. Kondisi keluarga yang demikian berpotensi terjadi pada keluarga yang tinggal di daerah pinggiran.

Pengertian Keluarga Fitzpatrick (2004), memberikan pengertian keluarga dengan cara meninjaunya berdasarkan tiga sudut pandang yang berbeda, yaitu pengertian keluarga secara struktural, pengertian keluarga secara fungsional, dan pengertian keluarga secara intersaksional. Pengertian keluarga secara struktural: keluarga didefinisikan berdasarkan kehadiran atau ketidak hadiran anggota keluarga, seperti orang tua, anak, dan kerabat lainnya. Definisi ini memfokuskan pada siapa yang menjadi bagian dari keluarga. Dari perspektif ini dapat muncul pengertian tentang keluarga sebaga asal-usul (families of 4 origin), keluarga sebagai wahana melahirkan keturunan (families of procreation), dan keluarga batih (extended family). Pengertian keluarga secara fungsional: keluarga didefinisikan dengan penekanan pada terpenuhinya tugas-tugas dan fungsifungsi psikososial. Fungsi-fungsi tersebut mencakup perawatan, sosialisasi pada anak, dukungan emosi dan materi, dan pemenuhan peranperan tertentu. Definisi ini memfokuskan pada tugas-tugas yang dilakukan oleh keluarga. Sedangkan pengertian keluarga secara transaksional: keluarga didefinisikan sebagai kelompok yang mengembangkan keintiman melalui perilaku-perilaku yang memunculkan rasa identitas sebagai keluarga (family identity), berupa ikatan emosi, pengalaman historis, maupun cita-cita masa depan. Definisi ini memfokuskan pada bagaimana keluarga melaksanakan fungsinya. Makna keluarga secara sosiologi (dalam Subhan, 2004) adalah kesatuan kemasyarakatan (sosial) berdasarkan hubungan perkawinan atau pertalian darah.

Sedangkan menurut Soelaeman (dalam Shochib, 2000), keluarga adalah sekumpulan orang hidup bersama dalam tempat tinggal bersama dan masingmasing anggota merasakan adanya pertautan batin sehingga terjadi saling mempengaruhi, saling memperhatikan, dan saling menyerahkan diri. Pengertian keluarga menurut Djamarah (2004) adalah suatu kesatuan yang diikat oleh adanya saling berhubungan atau interaksi dan saling mempengaruhi dengan yang lainnya, walaupun diantara mereka tidak terdapat hubungan darah. Fungsi Keluarga Keluarga juga dipandang sebagai institusi (lembaga) yang dapat memenuhi kebutuhan insani (manusiawi), terutama kebutuhan bagi pengembangan kepribadiannya dan pengembangan ras manusia. Apabila mengaitkan peranan keluarga dengan upaya memenuhi kebutuhan individu, 
maka keluarga merupakan lembaga pertama yang dapat memenuhi kebutuhan tersebut. Melalui perawatan dan perlakuan yang baik dari orang tua, anak dapat memenuhi kebutuhankebutuhan dasarnya, baik fisikbiologis maupun sosiopsikologisnya. Apabila anak telah memperoleh rasa aman, penerimaan sosial dan harga dirinya, maka anak dapat memenuhi kebutuhan tertingginya, yaitu perwujudan diri (self actualization).

Kondisi keluarga yang bahagia merupakan suatu hal yang sangat penting bagi perkembangan emosi para anggotanya (terutama anak). Kebahagiaan ini diperoleh apabila keluarga dapat memerankan fungsinya secara baik. Pembentukan Kepribadian Anak menurut Theodore M. New Comb merupakan organisasi sikap yang dimiliki seseorang sebagai latar belakang dari perilakunya. Menurut Roucek dan Warren (1962) kepribadian adalah organisasi faktor faktor biologis psikologis, dan sosiologis yang mendasari perilaku seorang individu.

Sedangkan

menurut Koenjaraningrat (2009) kepribadian adalah susunan dari unsur unsur akal dan jiwa yang menentukan tingkah laku atau tindakan seorang individu. Kepribadian merupakan hasil sosialisasi. Proses pembentukan kepribadian melalui sosialisasi dapat dibedakan sebagai berikut; sosialisasi yang dilakukan dengan sengaja melalui proses pendidikan dan pengajaran dan sosialisasi yang dilakukan tanpa sengaja melalui proses interaksi sosial seharihari dalam lingkungan masyarakatnya. Proses sosialisasi tersebut berlangsung sepanjang hidup manusia (sejak lahir sampai tua) mulai lingkungan keluarga, kelompok, sampai kehidupan masyarakat yang lebih luas. Melalui serangkaian proses yang panjang inilah, tiap individu belajar menghayati, meresapi, kemudian menginternalisasi berbagai nilai, norma, polapola tingkah laku sosial ke dalam mentalnya.

Dari berbagai hal yang diinternalisasi itulah seseorang memiliki kecenderungan untuk berperilaku menurut pola-pola tertentu yang memberi ciri watak yang khas sebagai identitas diri dan terbentuklah kepribadian. Masyarakat tempat mereka tinggal, secara sengaja atau tidak, selalu berusaha untuk mengarahkan dan memengaruhi anggota-anggotanya untuk selalu mematuhi nilai, norma, kebiasaan sehingga individu-individu tersebut bertingkah laku sesuai dengan harapan kelompoknya. Jadi, sesungguhnya sosialisasi itu merupakan aktivitas dua pihak, yaitu pihak yang mensosialisasi dan pihak yang disosialisasi. Dari proses tersebut, terbentuklah kepribadian yang berbeda antara masyarakat yang satu dan masyarakat lainnya. Misalnya, kepribadian orang Sunda berbeda dengan orang Batak. Pengalaman sosialisasi yang dilakukan masing-masing individu bisa saja berbeda. Kepribadian yang tumbuh 
pada masing-masing individu tidak akan mungkin sepenuhnya sama.

Oleh karena itu, seseorang dapat melihat keragaman kepribadian yang ditampilkannya dalam kehidupan sehari-hari. Misalnya, ada pribadi pribadi yang mempuyai sifat penyabar, ramah, pemarah, egois, atau rendah diri. Semuanya itu bergantung pada penyerapan dan pemahaman serta penghayatan nilai dan norma yang tumbuh dan berkembang dalam masyarakatnya. Adanya perbedaan kepribadian setiap individu sangatlah bergantung pada faktor-faktor yang memengaruhinya. Kepribadian terbentuk, berkembang, dan berubah seiring dengan proses sosialisasi yang dipengaruhi oleh faktor-faktor biologis, faktor geografis, faktor kebudayaan.

\section{PERMASALAHAN}

1. Beberapa konflik yang biasa terjadi antara remaja dengan orang tua hanya berkisar masalah kehidupan seharihari seperti jam pulang ke rumah, cara berpakaian, merapikan kamar tidur.

2. Konflik-konflik seperti ini jarang menimbulkan dilema utama dibandingkan dengan penggunaan obat-obatan terlarang maupun kenakalan remaja.

3. Beberapa remaja juga mengeluhkan cara-cara orang tua memperlakukan mereka yang otoriter, atau sikap-sikap orang tua yang terlalu kaku atau tidak memahami kepentingan remaja.
Akhir-akhir ini banyak orang tua maupun pendidik yang merasa khawatir bahwa anak-anak mereka terutama remaja mengalami degradasi moral. Sementara remaja sendiri juga sering dihadapkan pada dilema-dilema moral sehingga remaja merasa bingung terhadap keputusankeputusan moral yang harus diambilnya. Walaupun di dalam keluarga/orangtua mereka sudah ditanamkan nilai nilai, tetapi remaja akan merasa bingung ketika menghadapi kenyataan ternyata nilainilai tersebut sangat berbeda dengan nilai-nilai yang dihadapi bersama teman-temannya maupun di lingkungan yang berbeda.

Permasalahan akibat perubahan fisik banyak dirasakan oleh remaja awal ketika mereka mengalami pubertas. Pada remaja yang sudah selesai masa pubertasnya (remaja tengah dan akhir) permasalahan fisik yang terjadi berhubungan dengan ketidakpuasan / keprihatinan mereka terhadap keadaan fisik yang dimiliki yang biasanya tidak sesuai dengan fisik ideal yang diinginkan. Mereka juga sering membandingkan fisiknya dengan fisik orang lain ataupun idolaidola mereka. Permasalahan fisik ini sering mengakibatkan mereka kurang percaya diri.

Levine \& Smolak (2002) menyatakan bahwa $40-70 \%$ remaja perempuan merasakan ketidakpuasan pada dua atau lebih dari bagian tubuhnya, khususnya pada bagian pinggul, pantat, perut dan paha. Dalam sebuah penelitian survey pun 
ditemukan hampir $80 \%$ remaja ini mengalami ketidakpuasan dengan kondisi fisiknya (Kostanski \& Gullone, 1998). Ketidak puasan akan diri ini sangat erat kaitannya dengan distres emosi, pikiran yang berlebihan tentang penampilan, depresi, rendahnya harga diri, onset merokok, dan perilaku makan yang maladaptiv (\& Shaw, 2003; Stice \& Whitenton, 2002).

Lebih lanjut, ketidak puasan akan body image ini dapat sebagai pertemuan keluarga/orangtua awal munculnya gangguan makan seperti anoreksia atau bulimia (Polivy \& Herman, 1999; Thompson et al). Penggunaan alkohol dan obat-obatan terlarang akhir-akhir ini sudah sangat memprihatinkan. Walaupun usaha untuk menghentikan sudah digalakkan tetapi kasus-kasus penggunaan narkoba ini sepertinya tidak berkurang. Ada kekhasan mengapa remaja menggunakan narkoba / napza yang kemungkinan alasan mereka menggunakan berbeda dengan alasan yang terjadi pada orang dewasa. Santrock (2003) menemukan beberapa alasan mengapa remaja mengkonsumsi narkoba yaitu karena ingin tahu, untuk meningkatkan rasa percaya diri, solidaritas, adaptasi dengan lingkungan, maupun untuk kompensasi.

\section{PEMBAHASAN}

Di usia remaja akan banyak masalah dan tekanan yang akan dialami berkaitan dengan perubahan tersebut. Akhir-akhir ini banyak permasalahan remaja yang kerap muncul, permasalahan itu menjadi sangat kompleks dan memiliki dampak yang sangat buruk. Berikut beberapa permasalahan yang sering dihadapi remaja:

1. Adanya cyber bullying

Media sosial yang awalnya menjadi media untuk saling berbagi informasi justru kini menjadi media berbagi caci maki. Tindakan cyber bullying dapat dilakukan siapa saja melalui media sosial dan dapat pula dialami siapa saja, tak terkecuali remaja.

Sebaiknya Keluarga/orangtua sebagai orang tua berusaha mengontrol aktivitas anak di dunia maya, siapa saja yang menjadi temantemannya dan siapa yang dikenalnya melalui media sosial. Beri mereka pengetahuan mengenai media sosial dan bagaimana menggunakan media tersebut secara bijak.

2. Seks bebas

Seks bebas merupakan permasalahan remaja yang saat ini banyak terjadi. Hal ini akibat dari rasa ingin tahu remaja yang sangat besar yang tak diimbangi pengetahuan, dan mereka mencari informasi terkait seks melalui teman sebaya atau lewat internet. Sehingga berakibat fatal, justru mereka melakukan tindakan seks tersebut sebelum waktunya.

Sebaiknya hal ini Keluarga/orangtua antisipasi sejak dini. Kenalkan pendidikan seks 
sejak dini. Selain itu di sekolah juga harus diajarkan mengenai pendidikan seks namun masih dalam koridor pengetahuan. Selalu dampingi anak Keluarga/orangtua saat melihat televisi, majalah, atau membuka internet. Sebaiknya remaja bertanya langsung pada orang tua, guru, atau dokter mengenai seks sehingga tak keliru dan terjerumus pada seks bebas.

3. Minuman keras, rokok, dan narkoba

Masalah remaja yang satu ini sangat serius. Adanya sifat remaja yang mudah terpengaruh, selalu ingin tahu, dan ingin mencobacoba dapat membawa dampak buruk bila di dekat mereka terdapat hal negatif seperti rokok, narkoba dan miras. Jika lingkungan di sekitar mereka demikian bisa jadi akan berimbas pada remaja tersebut. Fungsi dasar keluarga adalah memberikan rasa memiliki, rasa aman, kasih sayang, dan mengembangkan hubungan yang baik di antara anggota keluarga.

Secara psikososiologis keluarga berfungsi sebagai : 1) pemberi rasa aman bagi anak dan anggota keluarga lainnya, 2) sumber pemenuhan kebutuhan, baik fisik maupun psikis, 3) sumber kasih sayang dan penerimaan, 4) model pola perilaku yang tepat bagi anak untuk belajar menjadi anggota masyarakat yang bak, 5) pemberi bimbingan bagi pengembangan perilaku yang secara sosial dianggap tepat, 6) pembentuk anak dalam memecahkan masalah yang dihadapinya dalam rangka menyesuaikan dirinya terhadap kehidupan, 7) pemberi bimbingan dalam belajar keterampilan motorik, verbal dan sosial yang dibutuhkan untuk penyesuaian diri, 8) stimulator bagi pengembangan kemampuan anak untuk mencapai prestasi, baik di sekolah maupun di masyarakat, 9) pembimbing dalam mengembangkan aspirasi, dan 10) sumber persahabatan/teman bermain bagi anak sampai cukup usia untuk mendapatkan teman di luar rumah.

Hubungan cinta kasih dalam keluarga tidak sebatas perasaan, akan tetapi juga menyangkut pemeliharaan, rasa tanggung jawab,perhatian, pemahaman, respek dan keinginan untuk menumbuh kembangkan anaka yang dicintainya. Keluarga yang hubungan antar anggotanya tidak harmonis, penuh konflik, atau gap communication dapat mengembangkan masalahmasalah kesehatan mental (mental illness) bagi anak. Dilihat dari sudut pandang sosiologis, fungsi keluarga dapat diklasifikasikan ke dalam fungsifungsi berikut:

a) Fungsi Biologis Keluarga dipandang sebagai pranata sosial yang memberikan 
legalitas, kesempatan dan kemudahan bagi para anggotanya untuk memenuhi kebutuhan dasar biologisnya. Kebutuhan itu meliputi (a) pangan, sandang, dan pangan, (b) hubungan seksual suamiistri, dan (c) reproduksi atau pengembangan keturunan (keluarga yang dibangun melalui pernikahan.

b) Fungsi Ekonomis Keluarga (dalam hal ini ayah) mempunyai kewajiban untuk menafkahi anggota keluarganya (istri dan anak). Maksudnya, kewajiban suami memberi makan dan pakaian kepada para istri dengan cara yang baik. Seseorang (suami) tidak dibebani (dalam memberi nafkah), melainkan menurut kadar kesanggupannya.

c) Fungsi Pendidikan (Edukatif) Keluarga merupakan lingkungan pendidikan pertama dan utama bagi anak. Menurut UU No. 2 tahun 1989 Bab IV Pasal 10 Ayat 4: "Pendidikan keluarga merupakan bagian dari jalur pendidikan luar sekolah yang diselenggarakan dalam keluarga dan yang memberikan keyakinan agama, nilai budaya, nilai moral, dan keterampilan".

d) Fungsi Sosialisasi Keluarga merupakan unit terkecil dari masyarakat, dan lingkungan keluarga merupakan faktor penentu (determinant factor) yang angat mempengaruhi kualitas generasi yang akan datang. Keluarga berfungsi sebagai miniatur masyarakat yang mensosialisasikan nilainilai atau peranperan hidup dalam masyarakat yang harus dilaksanakan oleh para anggotanya. Keluarga merupakan lembaga yang mempengaruhi perkembangan kemampuan anak untuk menaati peraturan (disiplin), mau bekerjasama dengan orang lain dan lain-lain.

e) Fungsi Perlindungan Keluarga berfungsi sebagai pelindung bagi para anggota keluarganya dari gangguan, ancaman atau kondisi yang menimbulkan ketidaknyamanan para anggotanya.

f) Fungsi Rekreatif Keluarga harus diciptakan sebagai lingkungan yang memberikan kenyamanan, keceriaan, kehangatan dan penuh semangat bagi anggotanya.

g) Fungsi Agama (Religius) Keluarga berfungsi sebagai penanaman nilainilai agama kepada anak agar mereka memiliki pedoman hidup yang benar. Keluarga berkewajiban mengajar, membimbing atau membiasakan anggotanya untuk mempelajari dan mengamalkan ajaran agama yang dianutnya. Bagi kebanyakan anak, lingkungan 
keluarga merupakan lingkungan pengaruh inti, setelah itu sekolah dan kemudian masyarakat. Keluarga dipandang sebagai lingkungan dini yang dibangun oleh orang tua dan orangorang terdekat. Dalam bentuknya keluarga selalu memiliki keunikan. Setiap keluarga selalu berbeda dengan keluarga lainnya. Sebaiknya orang tua selalu memberi pengawasan kepada anak remajanya, bukan berarti 24 jam menunggui-nya. Namun keluarga/orangtua dapat bangun komunikasi yang baik dengan si anak, mejadi sahabat mereka akan mempermudah keluarga / orangtua memasukkan perlahan-lahan nasehat dan pengertian akan hal yang positif dan negatif yang ada di sekitar mereka saat mereka terbuka untuk bercerita dengan Keluarga/orangtua.

4. Masalah di sekolah dan keluarga/orangtua.

Masalah di sekolah dan keluarga/orangtua kerap melatarbelakangi permasalahan remaja itu sendiri. Bisa jadi si anak merasa tak nyaman berada di rumah karena kurangnya perhatian orang tua yang sibuk bekerja. Bahkan bisa jadi si remaja ini mengalami masalah dengan teman di sekolahnya. Masalah di sekolah bisa jadi karena si remaja ini mengalami bullying. Sebaiknya untuk mengatasi permasalahan remaja ini, harus ada pembicaraan serius antara pihak sekolah juga orang tua, dan melakukan komunikasi dengan remaja.

Mengetahui permasalahan remaja sejak dini dan segera melakukan tindakan antisipasi sehingga tak berlanjut pada permasalahan remaja yang kompleks seperti yang telah disebutkan di atas. Pengawasan terhadap tingkah laku oleh orang dewasa sudah sulit dilakukan terhadap remaja karena lingkungan remaja sudah sangat luas. Pengasahan terhadap hati nurani sebagai pengendali internal perilaku remaja menjadi sangat penting agar remaja bisa mengendalikan perilakunya sendiri ketika tidak ada orang tua maupun guru dan segera menyadari serta memperbaiki diri ketika dia berbuat salah.

Dari permasalahan yang muncul disusun berbagai alternatif untuk memecahkan masalah. Selanjutnya dari berbagai alternatif, dipilih alternatif yang paling mungkin dilaksanakan.

1. Sebagian besar orangtua/keluarga kurang memahami akan pentingnya peran keluarga dalam mengatasi permasalahan remaja.

2. Meningkatkan kualitas pengetahuan para ibu-ibu Dasa Wisma tentang pemahaman remaja dan permasalahannya. 
3. Ceramah dan diskusi tentang pemahaman remaja dan permasalahannya

4. Penyuluhan usaha usaha mengatasi permasalahan remaja

Dalam menjalani masa yang dikenal dengan masa transisi, remaja akan mengalami banyak gejolak yang akan menjadi permasalahan yang tidak berdiri sendiri. Banyak faktor pemicu baik secara internal maupun eksternal yang membawa kekhawatiran yang berlebihan. Hal ini menyebabkan anak remaja menjadi mudah cemas, penakut, terkekang, dan bergantung kepada orangtua. Akibatnya, aktivitas terganggu dan kreativitas terbelenggu. Sebaliknya, jika orangtua memberikan kebebasan yang berlebihan juga akan menghancurkan hidup anak remaja mereka. Bagaimanapun juga, perlu diketahui bahwa tidak ada seorang remaja di muka bumi ini yang kebal terhadap masa krisis tersebut. Demikian juga, tidak ada remaja yang akan mengalami suasana krisis selamanya.

Oleh karena itu, kewajiban orangtua merupakan hal yang utama. Orangtua harus berusaha selalu memberikan teladan hidup yang baik sebagai refleksi atas iman. Masa krisis anak remaja tidak lepas dari campur tangan Tuhan. Dia mengizinkan krisis hadir dalam hidup remaja karena Dia tahu bahwa setiap masalah dan cobaan akan berguna untuk kebaikan. Remaja dapat bertumbuh dalam berbagai segi kehidupan secara rohani, mental, psikologis, dan emosional. Berbagai krisis akan membuat remaja berkembang karena menyediakan begitu banyak pula kesempatan untuk memperbaiki cara hidup. Maka dari itu, krisis masa remaja tidak perlu direspons dengan sikap negatif yang justru akan makin menjerumuskan mereka atau menimbulkan krisis-krisis lainnya. Sebaliknya, setiap krisis disikapi dengan sikap positif dan agar membuahkan kebaikan dalam hidup.

1. Salah satu aspek penting yang harus diperhatikan dalam perjalanan hidup seorang remaja adalah pembentukan identitasnya. Dalam pembentukan identitas, peranan orang tua sangat penting dan diperlukan karena mereka adalah teladan yang akan menjadi model bagi anak-anak remaja mereka. Bagaimanapun, orang tua adalah model yang paling mudah untuk ditiru oleh mereka. Artinya, apa yang diajarkan orang tua, akan merupakan identitas mereka menuju masa depan.

2. Orang tua yang bijaksana tidak akan membiarkan anak remajanya berjalan sesuka hati menuruti kehendaknya sendiri. Perlu ramburambu dan batasan-batasan peraturan yang tidak boleh dilanggar oleh mereka. Oleh karena itu, walaupun kurang menyenangkan, tetapi untuk membentuk kehendak remaja supaya tertib dan tingkah lakunya terkendali, diperlukan cara pendisiplinan yang keras dan tegas. 
3. Peran orang tua sangatlah peting bagi perlindungan remajanya terhadap pergaulan bebas, karena orang tua adalah orang yang paling pertama kali mendidik atau mengajarakan anaknya dari usia dini hingga dewasa.

\section{KESIMPULAN}

Keluarga/orangtua merupakan lingkungan pertama yang dikenal orang sehingga keluarga/orangtua merupakan penentu dasar dalam pembentukan karakter anak. Keluarga/orangtua memiliki peran penting dalam pertumbuhan dan perkembangan anak karena di lingkungan keluarga/orangtua anak akan mendapatkan kebutuhan yang diperlukannya, mulai dari kebutuhan jasmani ataupun rohani. Dalam sebuah keluarga/orangtua, orang tua mempunyai peran sentral dalam mengatur arah dan alur dari keluarga/orangtua tersebut. Orang tua selalu mengupayakan agar anggota keluarga/orangtuanya selalu dalam kondisi yang sehat baik secara fisik maupun psikis.

Seseorang yang memiliki tubuh yang sehat cenderung memiliki kondisi psikologis yg baik akan mempengaruhi perilaku tersebut. Dengan demikian tubuh yang sehat perlu diupayakan, oleh karena itu perlunya memperhatikan asupan nutrisi bagi tubuh. Disinilah fungsi orang tua terutama ibu, perlu memperhatikan asupan makanan untuk anggota keluarga/orangtuanya terutama anak agar mengkonsumsi makanan yang sehat. Oleh karena itu, setiap anggota keluarga/orangtua perlu sekali melaksankan segala fungsinya dengan baik.

Keluarga/orangtua juga sebagai institusi (lembaga) yang dapat memenuhi kebutuhan insani (manusiawi), terutama kebutuhan bagi pengembangan kepribadiannya dan pengembangan ras manusia. Apabila mengaitkan peranan keluarga/orangtua dengan upaya memenuhi kebutuhan individu, maka keluarga/orangtua merupakan lembaga pertama yang dapat memenuhi kebutuhan tersebut. Melalui perawatan dan perlakuan yang baik dari orang tua, anak dapat memenuhi kebutuhan-kebutuhan dasarnya, baik fisik-biologis maupun sosiopsikologisnya. Apabila anak telah memperoleh rasa aman, penerimaan sosial dan harga dirinya, maka anak dapat memenuhi kebutuhan tertingginya, yaitu perwujudan diri (self actualization).

Keluarga/orangtua yang bahagia merupakan suatu hal yang sangat penting bagi perkembangan emosi para anggotanya (terutama anak). Kebahagiaan ini diperoleh apabila keluarga/orangtua dapat memerankan fungsinya secara baik. Fungsi dasar keluarga/orangtua adalah memberikan rasa memiliki, rasa aman, kasih sayang, dan mengembangkan hubungan yang baik di antara anggota keluarga/orangtua. Kedudukan dan fungsi suatu keluarga dalam kehidupan manusia bersifat primer 
dan fundamental. Keluarga pada hakekatnya merupakan wadah pembentukan masing-masing anggotanya, terutama anak-anak yang masih berada dalam bimbingan tanggung jawab orangtuanya.

Perkembangan anak pada umumnya meliputi keadaan fisik, emosional sosial dan intelektual. Bila kesemuanya berjalan secara harmonis maka dapat dikatakan bahwa anak tersebut dalam keadaan sehat jiwanya. Dalam perkembangan jiwa terdapat periode-periode kritik yang berarti bahwa bila periode-periode ini tidak dapat dilalui dengan harmonis maka akan timbul gejala-gejala yang menunjukkan misalnya keterlambatan, ketegangan, kesulitan penyesuaian diri kepribadian yang terganggu bahkan menjadi gagal sama sekali dalam tugas sebagai makhluk sosial untuk mengadakan hubungan antar manusia yang memuaskan baik untuk diri sendiri maupun untuk orang di lingkungannya.

Keluarga merupakan kesatuan yang terkecil di dalam masyarakat tetapi menepati kedudukan yang primer dan fundamental, oleh sebab itu keluarga mempunyai peranan yang besar dan vital dalam mempengaruhi kehidupan seorang anak, terutama pada tahap awal maupun tahap-tahap kritisnya. Keluarga yang gagal memberi cinta kasih dan perhatian akan memupuk kebencian, rasa tidak aman dan tindak kekerasan kepada anak-anaknya. Demikian pula jika keluarga tidak dapat menciptakan suasana pendidikan, maka hal ini akan menyebabkan anak-anak terperosok atau tersesat jalannya.

\section{DAFTAR PUSTAKA}

Djamarah, S.B. 2004. Pola Komunikasi Orang tua dan Anak Dalam Keluarga:sebuah Perspektif Pendidikan Islam. Cet. I. Jakarta: Rineka Cipta.

Harting M, dkk. Dermal hypertrophies. Dalam: Wolff K, Goldsmith LA, Katz SI, Gilchrest BA, Paller AS, Leffell DJ,editor.

Fitzpatrick's .2008. Dermatology in General Medicine. Edisi ke-7. New York: McGraw-Hill; h.5506. 12.

Koentjaraningrat. 2009. Pengantar Ilmu Antropologi. Jakarta: Rineka Cipta.

Ritzer, George-Douglas J. Goodman. 2004. Teori Sosiologi Modern. Jakarta: Prenada Media.

Soerjono, Soekanto. 2012. Sosiologi Suatu Pengantar. Jakarta: Rajawali Pers.

Subhan, Z. (2004). Membina keluarga sakinah: Seri pemberdayaan perempuan. Yogyakarta: Pustaka Pesantren.

Shochib, M. 2000. Pola Asuh Orang Tua dalam Membantu Anak Mengembangkan Disiplin Diri. Jakarta: Rineka Cipta. 